\title{
To Be and Not to Be: Adaptation, Ambivalence and Ambiguity in a Danish Prison
}

\author{
Malene Molding Nielsen \\ Department of Sociology, University of Copenhagen, Copenhagen, Denmark \\ Email: malene@molding.dk
}

Received March $1^{\text {st }}$, 2012; revised April 5 ${ }^{\text {th }}$, 2012; accepted April 22 ${ }^{\text {nd }}, 2012$

\begin{abstract}
In a recent article on Scandinavian Exceptionalism, John Pratt urges that in era defined by a pre-occupation with penal excess, we need to explore what we can learn from the Scandinavian regimes characterized by low levels of imprisonment and exceptional prison conditions. This paper complements Pratt's comparative historical work by scrutinizing the realities of people living and working inside one Scandinavian penal regime. It explores prisoners' experiences of and adaption to institutional life focusing on implementation of security and order and the motivational and supportive work. It describes a thriving copresence of bewildering realities where prisoners' adaptation is defined by a straining uncertainty, ambiguity and ambivalence, and where moral divides are united in the Modus Vivendi of everyday life. In this context prisoners are expected to express regrets and aspire to reform by demonstrating they are morally on course and motivated to commence a life without crime. Instead prisoners mostly use the institutional reformative stimuli to pursue their own ends that are foreign to the system. The study describes a discrepancy between penal ideals and practices and suggests that penal realities as they are experienced from within may not match the level of exceptionalism that Pratt observes from the outside.
\end{abstract}

Keywords: Moral Complexity; Institutional Logic; Adaptation; Ambiguity; Ambivalence; Prison Life

\section{Introduction}

In a recent award winning article that reports a comparative study on Scandinavian penal regimes, John Pratt describes the regimes as exceptional both with regard to their low levels of imprisonment and the material prison conditions (Pratt, 2008). He argues that in an era defined by a pre-occupation with penal excess, there is a need to change course and focus on what we can learn from exceptional regimes like the Scandinavian. While Pratt's historical analysis and project is both interesting and sympathetic, it does not, focus on the life worlds' and realities of people who live and work inside penal institutions. This paper complements Pratt's broad and comparative analysis by providing a snapshot of a Scandinavian penal regime from within. It scrutinises prisoners' experiences of and adaptation to institutional life as it unfolds in relation to security and control and the penal supportive and motivational work in a Danish open prison.

I argue that prisoners' experiences of and adaptation to prison life are first and foremost characterised by ambiguity and ambivalence that are enacted by officers and prisoners when they collaborate on the production of the Modus Vivendi that makes daily life. It is a Modus Vivendi characterised by pretence, negotiations, trade-offs and straining levels of uncertainty that accompany multiple formal and informal agendas and realities relating to security and control and the motivational and supportive penal work. I explain how, in this ambivalent and ambiguous penal context, it is difficult to establish a sense of safety and engage in a dialogue with staff on how to demonstrate motivation and start afresh without crime. I describe how prison daily practices make it challenging to distil what is morally on course from what is morally astray, hence, making penal realities - as they are experienced and enacted from withinpainful, uncertain and difficult to navigate. The study describes a discrepancy between the realities of penal practices and formal penal ideals; a discrepancy that comes with yet another call to rethink the implementation of punishment.

\section{Adaptation: Doing, Being and Experiencing}

There is no single pattern of adjustment to prison life (Crewe, 2005). A wealth of studies have added to the seminal work of Gresham Sykes and Erving Goffman who emphasised the importance of internally managed deprivations (Goffman, 1961; Sykes, 1958), and to that of Donald Clemmer who regarded adaptation as an assimilation process defined by parameters such as social exposure and time spent in prison (Clemmer, 1958). While contemporary scholars acknowledge the influence of confinement on identity, they argue that individuals carry their culture and personal histories with them inside penal institutions where they are carefully managed (Cohen, 1994). Place of origin (Crewe, 2009), ethnic affiliation, gang life (Jacobs in Crewe, 2005), personal background, type of crime, age, networking capabilities and mental health, therefore, also affect prisoners' well-being and adjustment (Crawley and Sparks, 2005; Crewe, 2009; Harvey, 2005; Liebling, 1999; Mathiesen, 1965). To this list, I could include penal policies, staff composition and cultural and historical differences between penal institutions (Liebling \& Arnold, 2004; Liebling \& Maruna, 2005). In this article, I will primarily focus on prisoners' networks in- and outside prison and the institutional logic that accompanies penal policies and interaction.

To explain and analyse how security, control and order, and aspects of the penal motivational and supportive work shape 
prisoners' adaptation to and experiences of imprisonment, I will draw on Annemarie Mol, particularly, her work on disease (Mol, 2002). In conceptualising ontology as enacted, she merges being and doing and situates ontology in hospital daily interactions where she observes how Atherosclerosis is done. With detailed ethnographic observations in and around hospital departments, Mol unravels the co-existent, multiple realities of Atherosclerosis. She documents how these realities are enacted differently in diverse departments, but how they are interrelated in hospital everyday practices where the differences between them are bracketed, and they make the disease. With Actor Network Theory and the mathematical notion of intransitivity, Mol demonstrates how these diverse enactments of Atherosclerosis "contain each other" because they are related, i.e., A includes B and B is also inside A, while, simultaneously, they are ontologically incompatible (Mol, 2002). It is against this background Mol argues, it is possible to understand Atherosclerosis as more than one disease, yet, less than many.

With her radical empiricist perspective on social life, Mol does not aim to account for life worlds and experiences and, as such, her analysis and approach differ from mine. In this analysis I am, nevertheless, inspired by her praxis-related approach because it allows me to analyse enactments of safety and order in prison as practices that are co-produced by officers and prisoners; practices that are related, therefore, and that include diverse realities. I identify, at least two, divergent realities that shape prisoners' adaptation to and experiences of imprisonment: one relating to formal penal ideals and practices established to implement punishment in a secure and orderly environment, and another relating to prisoners' codes, conventions and ideals. Inspired by Mol's work on Actor Network Theory and mathematical intransitivity, I have been able to unite these realities that tend to be accounted for and addressed as separate and distinct in prison research and, as such, this paper offers an alternative account of adaptation. In drawing on Mol who emphasises the enacted nature of social life, I simultaneously emphasise and add bodily rooted dimensions to ambiguity and ambivalence. I so doing, I give primacy to the experiencing body whilst honouring the realities I observed in prison.

To connect enactments with emotional experiences and describe how ambiguity and ambivalence come to constitute pivotal characteristics of being in prison as a being-in-the-world (Gieser 2008), I draw on Vinciane Despret, in particular, her work on emotional theory (Despret, 2004). Despret argues that in emotional theory, it is difficult to distinguish between cause and effect because emotional experience belongs to a sphere where neither world, nor body, nor consciousness can be clearly separated and distributed (Despret, 2004). Instead she maintains that the body and what affects it produce each other, hence tying enactments to emotional life and experience.

Finally, I use Michel de Certeau's work (de Certeau, 1988) to describe prisoners' adaptive strategies vis-a-vis institutional routines, aims and expectations. In explaining the operations and manipulations of the dominated, de Certeau scrutinises the ambiguity that subverted the Spanish colonizers in imposing their culture on indigenous Indians. Submissive, and even consenting to their subjection, the Indians often made of the rituals, representations and laws imposed on them something quite different from what their conquerors had in mind (de Certeau, 1988). They subverted them, not by rejecting or altering them, but using them with respect to ends and references foreign to the systems they had no choice but to accept (de
Certeau, 1988).

\section{Research Context and Approach}

This analysis is one result of an ethnographic study conducted in a Danish open male prison during a period of 10 months. With a phenomenological understanding of ethnography, I acknowledge that being can never be accounted for with reference to the subject alone. Being is inter-subjective and related to the world that surrounds us (see e.g. Rendtorff, 2004) as a being-in-the-world that is fundamental for generation of data and our interpretations of experience. However, although I seek to describe prisoners' experiences of their social existence and practical activities that phenomenologists would refer to as the life world (Jackson, 1996), there is a disjunction between the world and our understanding of it (Husserl in Hastrup, 2005). When I account for experiences, I refer to prisoners' articulations of experiences as they surfaced in daily interaction and in formal and informal interviews. As such my accounts are informed interpretations of my observations and interactions with people who lived and worked in prison.

Throughout the study period I conducted informal interviews whilst observing staff-to-prisoner, staff-to-staff and prisoner-toprisoner interactions in and around two prison wings ${ }^{1}$. My informal presence and interviews were complimented by formal semi-structured interviews conducted with two representatives of middle management, one with a senior manager and a randomly selected half of the prisoner and officer populations, i.e., with 19 prisoners and 13 prison officers. All but one of these interviews were recorded and transcribed. My observations were documented, mostly, by the end of each fieldwork day. To this end, I sought to recall native language and capture the observational context. The material I present here stems from both informal observations and conversations and formal interviews.

Although there are important differences between the Scandinavian regimes with regard to penal history, criminal law and sanctions (Pratt, 2008; Uglevik \& Dullum 1212; Graunbøl et al., 2010), the Danish regime resembles, in many ways, the Swedish and Norwegian as described by Pratt. The Danish penal regime is fostered on egalitarian values and ideals (Borish, 1991) maintaining that punishment should not go beyond deprivation of liberty, and that prison life should, to the extent possible, model life outside the penal context (Engbo, 2005). It is rooted in welfare state security, has a history of low levels of imprisonment (Christie, 2001; Kristoffersen, 2010) and, in recent years, it has undergone changes defined by more and longer-term sentences, a tightening of security and control and an enhanced focus on demonstrating results. Furthermore, Danish prison conditions are what Pratt would refer to as both humane and liberal.

In Denmark prisoners, ideally, serve time in penal institutions located in relative proximity to their home town although the Prison and Probation Service may decide against it if capacity is limited or it is otherwise considered unjustifiable. The relatively liberal organisation of everyday life and the mostly short geographical distances may account for the importance attached in this analysis to prisoners' external networks, and the extent to which they pursue their own agendas in their engagements with the penal institution.

\footnotetext{
${ }^{1}$ These wings did not offer any drug, alcohol or related treatment schemes. A special wing was established to cater for prisoners who wanted to enrol in such programmes.
} 


\section{Enacting Security and Threat}

As elsewhere, the Danish prison infrastructure and formal division of labour exhibit penal ideals for institutional interaction. They manifest who guards and who is guarded and, they direct the construction of persons classified by difference in social quality and moral character, as Goffman has convincingly described (1961). While such penal ideals certainly frame the interaction of the Danish officers and prisoners, other divergent realities characterised by their unofficial nature and unwritten rules have a simultaneous presence. As my interview transcript below demonstrates, the co-presence of formal and informal ideals and practices typically surface as trade-offs and compromises that make the Modus Vivendi of everyday life and that are accompanied by un-predictability and uncertainty.

James is serving time and contrary to the majority of prisoners I meet, James did not have a criminal career and lifestyle prior to conviction. Therefore, he has no practical sense of what it takes to manage prison life. While James' experience is not surprising, it is illustrative because the tacit and informal rules and regularities that guard everyday interaction surface when James violates them and demonstrates his social inadequacies.

James: "I tried to explain, they (the other prisoners) had to take into consideration I have another background (not criminal).”

Interviewer: "You said that?"

James: "Yeah. So they slapped my face and things like that and kept on making all sorts of remarks and things-because they sensed I am different. I don't have tattoos or anything...so I told them; 'I'm not used to this kind of life."”

Interviewer: "Were you afraid?"

James: "Yes, I was shocked when he slapped me."

Interviewer: "Did you defend or protect yourself?"

James: "No. I told him; 'you'll not get far with that behaviour, I'll go straight to the officers and report you'."

Interviewer: "Did you say that?"

James: "Yes, and I actually went into the office and told an officer what had happened, and she explained how it works in here. She said; 'you can't report an incident like that. If you want us to react, it has to be more serious-otherwise you're just making your own life complicated.' I got her message because afterwards several of the other prisoners asked: 'You didn't report the slapping, did you?' and I replied; 'Yes, I did, because I didn't know what else to do.' But then it sorted itself out because my roommate, Danial, he knew Ben (prisoner), and Ben told them (the prisoners who harassed James) that if they ever even looked at me again, he and Hans (prisoner) would make sure they would never walk out of here. That's how you have the prisoner hierarchy...so that saved me. I felt threatened, you know. They always approached me two at a time...”

As should be evident, James' inexperience reveals itself when he does not embrace the possibility of earning respect by demonstrating aggression, strength, fearlessness and a willingness not to submit by striking back (Crewe, 2009; Einat, 2005). It also surfaces in his initial naive belief in the institutionally defined authorities and their ability to support him. As one prisoner, who has spent years moving in and out of prisons, has it: "From time to time you get people (prisoners) who have no sense of how you operate in here and there has to be space for them to serve time as well."

The interview captures one important event from the beginning of James' short-term prison experience that comes to in- fluence the way he chooses to manage the rest of his time. He does not report fellow prisoners again, and he continuously spends time securing good-will among inmates hoping this will earn him respect and protection if he is threatened another time. James is on guard, socialising and networking and, in so doing, establishing a sense of safety, order and control.

Like other first time prisoners (Harvey, 2005), James is troubled. Young prisoners without a network or who otherwise appear vulnerable upon arrival tell stories that resemble James'. They are stories that point to the importance of creating respect and defining your position and reputation in relation to the inmate social hierarchy. Both officers and prisoners are aware of this, accept it and act accordingly. James' Contact Person literally advices James to leave the incident unreported to avoid negative sanctions from other prisoners who are likely to think of him as an informer. Furthermore, James' roommate refers James to Ben and Hans, two prisoners with social and economic capital, whose presence and reputation in prison guarantee James' security that officers are not in a position to cater for at that point.

The incident illustrates key informal principles of the Modus Vivendi where the real distribution of power is different from that which is formally claimed because the attempt to realise power is structurally defective (Sparks and Bottoms, 1995). Staff make the prison run, but they do not run the prison (Crewe, 2009) alone: the officer-prisoner relationship is characterised by reciprocity and officers' reliance upon inmate codes and conventions as a means to establish a relatively peaceful environment for serving time and running daily life. This comes across, e.g., when older experienced prisoners explain to me, how they have an interest in maintaining order and security to avoid the presence of officers on the wing, thereby making the most of their time and safeguarding a sense of privacy.

It is, therefore, not surprising that James' relationship with prisoners is characterised by ambivalence defined by a simultaneous experience of security and threat. Prisoners not only constitute danger because they threaten him, they (Ben and Hans) also represent his rescue because they put an end to the harassment which the officer is not in a position to. It is from this perspective that prisoners come to surface as strong and powerful, vis-a-vis staff, despite their seemingly weak position. This does not imply that staff have no role to play with regard to order and safety. The daily monitoring of prisoners and their whereabouts, the cell searches and the regular transfer of prisoners to solitary confinement exemplify security aspects of the officer role.

James relationship with staff is not unambiguous either. By pointing to the importance of developing a positive relationship with other prisoners, instead of reporting them, and by indicating there is help ahead, if violence and threats from the other prisoners escalate, James' Contact Person offers, on the one hand, immediate support and potential, although conditional, rescue. On the other hand, she announces, she is not in a position to help James in a situation where he feels insecure and threatened, hence leaving James in a distressing and ambiguous place. His interaction with prisoners and staff evokes conflicting feelings that come across, e.g., when he explains; he feels safe (after three months) but, nevertheless, continues to do other prisoners favours to make sure they owe him one. In practice, prisoners' sense of security, control and order stems both from the formal ideals and practices of the system and the 
informal ones that are united in the experience of imprisonment.

In discussing how, in emotional theory, cause-effect relationships blur Despret asks: "am I scared because the world is terrifying or is the world terrifying because I am scared?” In so doing, she points to how emotions belong to a sphere of experiences where casual relationships are difficult to distinguish and neither world, nor body, nor consciousness can be clearly separated and distributed (Despret, 2004) rather: the world affects the mind and the mind the world. It is when the body and what affects it produce each other that Despret argues; we make ourselves available to the world. Although I recognise that availability in prison is enforced, I will argue that James' being in prison is defined in a similar way: he is simultaneously affecting it and affected by it. He feels both threatened and secure and he acts on these feelings that come to influence how he experiences and chooses to manage everyday life. In letting the other prisoners harass him, James participates in enactments of threat and, in accepting help from his network among prisoners, he enacts safety. Or with Despret's frame of thinking, James makes himself available to security and threat. He feels and enacts secure and threatened, making ambivalence and ambiguity defining features of his being-in-prison as it unfolds in everyday life, his relationship with the other prisoners and with staff. It is from this perspective that ambiguity and ambivalence become dominant embedded characteristics of prison life.

Although James' story is unique because it simultaneously points to a lack of network, inexperience and inability to navigate criminal codes and conventions, the thriving co-presence of ambivalent and ambiguous feelings and enactments also come across in my interviews with other prisoners as a common feature of their existence in prison.

I also observe ambivalent feelings related to power. An experienced prisoner, Tim, describes to me how imprisonment makes him feel powerless and out of control, yet, when we discuss ethnic tensions on the wing he explains: “...And staff, well staff, they are actually relieved we (socially powerful prisoners) are here because we can manage them (ethnic minorities) which they (staff) are not able to." The reality of prison life is defined by a complex blend of severe feelings and beings such as being and feeling powerful and powerless. They are discrete feelings and beings that co-exist and are connected in practice because the location of powerful in everyday life is often also the location of powerless.

With Mol in mind, one could argue that security, control and order are established and enacted differently by officers and prisoners because they are guarded by divergent ideals, conventions, norms and practices. With separate value systems, moral orientations, legal statuses, codes and conventions, and with different levels of transparency, the criminal world and that of the penal system are ontologically incompatible. However, their differences are bracketed in practice where the order and safety prisoners establish is mostly acknowledged by officers because it allows officers to operate relatively smoothly and vice versa. The realities of officers and prisoners are intertwined in prison life as one makes possible the enactment of the other. As Mol has it, to be is to be related (Mol, 2002), and it is from this perspective that one includes the other. Both officers and prisoners make order and security, and, in so doing, they become a part of each others' realities. As enacted and related realities the criminal world and penal system and ideals unite in experience.
Although an element of predictability characterises these incompatible, yet, intertwined enacted realities, they are also unpredictable because they are enactments, and as enactments, they are dynamic and subject to change. It is this unpredictability that evokes doubt about what realities frame everyday life and when. James, e.g., does not know when his experience of being insecure may qualify for staff assistance, and he never knows, when he has networked and socialised enough with prisoners to secure himself.

\section{Adaptation: Internal and External Networks}

Whether prisoners are transferred from a maximum security prison, from a detention or come directly from home, most prisoners I meet draw on their established social networks when they settle in. They have a sense of how to operate the criminal codes and conventions and, therefore, they are better prepared than James.

While serving time, the adaptation of most prisoners and their sense of security, control and order depend to a large extent on their networking capabilities in- and outside of prison. Danial, a prisoner who was previously a full-time criminal, pedagogically explains;

"As in other spheres of life, introduction matters. I've a friend whose friend, Tim, serves time here so when I arrived my friend asked Tim (an influential prisoner) to receive me. So when I checked in, Tim called Hans, introduced us and asked Hans to look after me-that's why I know Tim now... So if something bothers me, I talk to Tim about it, and he'll sort it out. He has been here a long time... I look after Brian, the little guy, but I also expect him to do me a favour, if I ask for it. That's how it works... In this way, you end up knowing a lot of people."

Prisoners hang out in cliques defined by a variety of factors such as their criminal networks and interests, personal talents, age and attitude to imprisonment. Apart from providing for each others' safety, they use their networks to socialise and pass time and share information about the informal and formal workings of the prison and the services it provides. At all levels in the prisoner hierarchies, prisoners' use these networks strategically. As Jimmy (prisoner) describes it:

"The older you get, the more you think about what you do, and if you're planning to remain criminal, you may think; "oh well, it's a bad idea to fall out with him because if I do, I'll close the door behind me at the expense of good contacts and potential business opportunities.”

Outside realities have a strong presence inside prison in terms of shaping prisoners' networks, alliances and activities. In shaping prisoners' networks, social life and sense of security inside, outside realities also influence how prisoners interact with officers, and officers' abilities to effectively intervene and comprehend prisoners' affairs. As realities operating from outside, they surface only subtly in the alliances and obligations that shape prisoners' networks and that are not always visible to staff. In penal institutions prisoners are units in a wider network that illuminate the functionality and usefulness of alternative, informal networks, rules and approaches to life.

This does not imply that the penal system has no significance in terms of shaping prison life. Staff composition and professional orientation, the implementation of new policies or the public resources invested in penal institutions obviously influence daily life. In general, however, I observe that staff play 
a limited role when prisoners' settle in both in terms of their capacity to intervene-as James's story illustrates - and also in terms of providing information to prisoners about prison routines and life and the possibilities they offer. Whether prisoners are novices, like James, or experienced criminals, they have to take into account the multiplicity that characterise enactments of security, control and order. Furthermore, they have to cope with the uncertainties, ambiguities and ambivalences that the intertwined realties generate; realities that prisoners and staff enact and embody.

\section{Puzzling Dialogue}

The first of April 2004 a new penal policy was introduced in Denmark. In effect the policy rewards prisoners an early release, i.e., half time, if they demonstrate a special effort to start afresh without crime. Along with other policies ${ }^{2}$, this policy provided directions for the implementation of the Prison and Probation Service mission: to complete punishment with control and security, and support and motivate convicts to live a life without crime through personal and social development (Kriminalforsorgen, 2000).

Although the first of April 2004 policy, in practice, involves only a fraction of the total prisoner population (RoPaD, 20062009), the way in which prisoners respond to it exemplifies well how I generally observe prisoners adapt to and navigate the possibilities and constraints of the penal system. As such, the response of prisoners to this policy provides a typical example of institutional penal interaction relating to the supportive and motivational work.

The possibilities available for convicts to demonstrate their non-criminal aspirations typically involve participation in offender behaviour courses, e.g., cognitive skills programmes, and anger management- and drug programmes (RoPaD, 2006). Other possibilities relate to prisoners' educational skills and their efforts to improve these. The policy, hence cultivates compliance with the moral values and normative orientation of mainstream society and the capabilities of individuals to lead a life without crime.

Prisoners who decide to pursue an early release typically regulate their behaviour or align it with institutional goals as they sign up for different programmes or apply for courses. In so doing, they appear to take responsibility for their own personal development (see also Bosworth and Carrabine, 2001; Crewe, 2007) whereby one could argue that aspects of accountability and governance shift from the institution to the individual prisoner.

Not all prisoners are equally competent or strategic in terms of the way they choose to navigate institutional possibilities. Kim, an educated prisoner with a job on stand-by outside, confides with me that he is planning to apply for an early release, and he had looked, therefore, at ways in which it will be sensible for him to demonstrate his aspirations to start afresh. But how do you express will and motivation in a penal institutional context? With what you say or do, or with what you refrain from saying or doing? As my fieldnote extracts below illustrate this is not an easy task.

Kim: “I don’t want to apply for an apprenticeship or a truck

${ }^{2}$ Other initiatives introduced in this period included, e.g., the implementation of a zero drug tolerance with mandatory drug testing; an initiative that likewise promoted compliance with rules and regulations (Flerårsaftale, 20042007). licence-as most people do. I have applied for a course that adds to the educational background I already have. I have been discussing this with the prison for months now-the idea being, of course, eh... I apply for an educational course so I can get an early release. But I am stuck. When the social workers here call the Prison and Probation Service at the Municipality, staff at the Municipality claim they provide financial support to such courses whereas the social workers and the officer here (Kim's Contact Person) argue that, if you already have an education, the Prison and Probation Service doesn't support additional courses. Meanwhile, time passes and now I have so little time left, it nearly doesn't make sense to apply anymore."

As Kim clarifies his application process has been long and painful, and when I leave, i.e., ten months after he started to prepare for an early release, his application is still not processed or approved, and Kim has served half time months back. I understand that Kim has had a conflict with the social workers and his Contact Person on what he experiences as bureaucratic inefficiency, lack of transparency in decision making processes and slow progress. When I meet Kim's Contact Person I learn that Kim initially told him (the Contact Person) that he (Kim) would apply for an educational course in order to get an early release. The Contact Person tells me:

"I told Kim, he has to do something exceptional to get an early release, and he hasn't. So, Kim tells me, he'll apply for an education in order to get an early release, although, he knows, he'll never make use of it. It doesn't make sense to apply for an education, if you know, you'll never use it... so he'll have to apply, and we'll have to reject his application.”

Kim's story resembles those of other prisoners who staff come to look upon as unreliable and difficult. They become prisoners who take advantage of the system; prisoners who pretend to be, do or want things that do not correspond with reality, in this case applying for a course Kim does not believe he will ever use. They become prisoners who staff do not trust and, therefore, resist. As Kim's Contact Person rationally notes: "It doesn't make sense to apply for an education, if you know, you'll never use it..." In revealing that he actually wants an early release and, therefore, applies for an educational course, instead of simply and subtly expressing, he is planning to take a training course because he wants to reform his life or seeks to improve himself, Kim comes to appear insincere. The application process accentuates the image of Kim as a kind of person who does not subject to collectively defined ideals and ideas of right and wrong; a criminal who is morally astray.

Similar to the role religion was ascribed by prison reformers in the establishment of the modern Danish prison during the second half of the nineteenth and the first half of the twentieth century (Scharff Smith, 2003), the implementation of the new policy extends the moral project of the institution. This is a moral project where the ideal prisoner is expected to reform and repent; a moral orientation also observed in recent studies of social work (Jarvinen \& Mik-Meyer, 2003). In this study reform refers to a morally informed change in the individual prisoner towards compliance with collectively defined ideals of right and wrong. Repent refers to an institutional expectation towards prisoners to express regret. I will primarily focus on reform in this analysis.

The moral project likewise reflects the orientation of Danish penal policies from the beginning of the twentieth century and until the 1970 ties that were marked by a treatment ideology. 
Crime and deviancy were considered pathological, and crime was essentially related to the individual rather than to society's failure to cater for its citizens and, as a result, it could only be attended to through treatment and moral rehabilitation. The last three decades have seen a rejuvenation of the treatment ideology although treatment now has a status similar to that of education and employment (see also Engbo, 2005).

The moral project emerges as an ideal in staff discussions and assessments of prisoners, and it surfaces in institutional expectations, i.e., in what is said, done, rewarded and punished. For example, upon arrival of re-offenders, or when they leave prison, I often hear staff saying either: "so you didn't get the message," or "you better learn to behave," indicating, in a friendly tone, the moral distinction between staff and prisoners and the necessity of prisoners to continue to aspire for reform.

While it is possible Kim aspires to reform and regrets his criminal acts, he does not communicate it in a way that owes justice to the institutional moral logic and imperative. To appropriately honour the moral project, Kim should ideally express determination to reform through the choices he makes. In addition, he should silence any personal doubts about or deviations from institutional ideals; a behaviour that requires strategy, self-control and discretion. As should be evident from the fieldnote extracts, you certainly do not reveal the possible missing link between the relevance or quality of institutionally available possibilities such as training courses and offender programmes, your aspirations to reform your life and start afresh, and your plea for release.

Another prisoner, Hans, convincingly explains how it should be done. Hans confides with me, he uses other prisoners to scrutinise and plan the possibilities for an early release; in this case, a release that includes participation in a training course outside prison during his last months of confinement:

"When my Contact Person comes, I'll have everything in control, you know, so I appear to be a person with a drive; a person who has a plan, you know, instead of saying-ehh, I don't know, what I want, I just want a life where I get out of prison every day-that doesn't really work, you know."

As the extract from my interview with Hans illustrates, most prisoners are aware how they should appear in order to conform to the penal moral project. This does not imply that some prisoners do not withdraw from contact with staff altogether, but it implies that those who engage with staff mostly plan their engagements carefully. It also does not imply that prisoners do not think they might benefit from the educational and other skills, they may acquire whilst attached to the prison system. However, they mostly express, they use their participation in offender or educational programmes to get a good report or to spend parts of their day outside prison so they can attend to other interests, in particular, being in regular contact with family, partners and friends, or maintain different income generating activities. It also does not imply, they cannot reveal to staff their strategic interests or "amoral" thinking. This, however, is typically done with a smile that frames such utterances as humorous only.

As my field work progresses, I come to realise that prisoners are not rewarded with the benefits on offer through penal policies and daily practices if, like Kim, they do not manage to circumvent the moral project by carefully disguising their aspirations. The puzzling concern related to this observation is, of course, that Kim transparently reveals what he (and most other prisoners) intends to do, and that he from this perspective is both sincere and trustworthy. His transparency and trustworthiness are not rewarded, however, because his intentions are not considered legitimate and in line with the ideal implementation of the penal moral project and policy.

In other words, while Kim was punished with exclusion from society because he did not behave in accordance with collectively defined ideals of right and wrong, i.e., he was unreliable and jurisdictionally and morally astray-he may have been rewarded with goodwill or a rapid inclusion back into mainstream society, had he convincingly pretended to be reliable and morally on course. Meanwhile, prisoners, like Hans, who are strategic in their communication with staff; they are the ones who benefit from staff goodwill and, at times, possibly also an early release.

As such and in comparison with the penal institutional work related to security and control, the supportive and motivational work is also characterised by ambiguity and ambivalence. In so being, ambiguity and ambivalence not only typify the institutional logic and incentive system, it cultivates specific kind of clients: prisoners who simultaneously enact and embody compliance and non-compliance.

\section{Adaptive Strategies: Soft Power, Resistance, or Means to Personal Ends?}

If one uses a Foucaudian perspective, it is difficult not to understand the self governance and endless manoeuvring and circumvention of the system as a blend of resistance, i.e., reactions to the disciplinary grip of the penal regime, and manifestations of soft power. With soft power I refer to versions of power that do not constrain, command or suppress the individual as much as stimulate the subject, and where the distinction between choice and necessity is, therefore, blurred (Crewe, 2009; Garland, 1997).

While this is probable, the interpretive road I will take, in this analysis, is simply to note that prisoners' compliance and aligning of their behaviour with the expectations of governing authorities is, mostly, impression management implemented as opportunist and pragmatic attempts to pursue personalised ends. In other words, while penal institutional life clearly is sought to stimulate individuals to proactively take responsibility for their own development and improved moral performance, the stimulation mostly, does not imply moral or normative compliance. Prisoners rather use available stimuli as means to other ends.

Time and again prisoners describe how they use rules and regulations to advance their own agendas both in and outside prison. Thomas, e.g., has a small company that he would like to attend to from prison which has not been easy to organise. Like many other prisoners, he has used official rules and procedures to make this possible, and he has had to accept both frustrations and delays related to the penal bureaucracy. When I meet him, he has successfully established himself in a position where he is formally doing an apprenticeship that is being monitored with control calls and visits while, in reality, and through an informal set-up, he is attending to his company.

Another prisoner, Frank, describes to me how, in a similar fashion, he used his high blood pressure as an excuse to get a cell on his own thereby avoiding to share a cell with a prisoner he dislikes (prisoners are initially placed in a cell that sleeps two).

Frank: "When you have been in and out of prison, like me, you get to know a few tricks." 
Interviewer: "Yeah?"

Frank: "So I got hold of my General Practitioner (GP) who wrote, eh, if you know your GP you can sort out things. So the GP wrote to the prison nurse."

Interviewer: "And then you what?"

Frank: "Well, then, when I got my pills (against high blood pressure), I just didn't take them, and then my blood pressure went up. So when I went to the prison doctor, well then, I got a room on my own very fast-cause I needed calm, right?!”

Frank does not question, he has to share a cell with another prisoner. Instead, he uses one local authority, the prison nurse, to push for a single room in a way that is considered legitimate in the penal system. By not taking the pills his GP prescribed, Frank demonstrates, how his blood pressure rises in relation to imprisonment, and how, urgently, he needs calm and a room on his own.

Frank and Thomas have their own references and ends and similar to how de Certeau depicts the reaction of Indians to their colonizers (de Certeau, 1988): they make of the rituals, representations and laws imposed on them something quite different from what their conquerors have in mind. They subvert them not by rejecting or altering them, but by using them with respect to ends and references foreign to the system they have to accept (de Certeau, 1988). In so doing, they deflate its power and come to appear to escape the regime without leaving it.

In pursuing their own interests, prisoners draw on their personal talents, institutional experiences and criminal habitual behaviour that for obvious reasons promote oppositional values but that do not necessarily come about as a reaction to the penal regime per se. While Thomas clearly expresses he regards the police and the penal system as his enemies, his accounts of how he handles both in-and outside of prison, respectively, do not differ radically: both in-and outside prison he acknowledges their official status and devices strategies to circumvent them. As such, the adaptive strategies of Thomas, Frank and many other prisoners bring to light the furtive forms taken by groups or individuals who make the most of imprisonment.

\section{Concluding Discussion: To Be and Not to Be}

In analysing prisoners' experiences of and adaptation to prison life, as I have done in this text, the being and doing of officers and prisoners merge in a praxis-bound ontology at the expense of a clear moral divide as, e.g., Goffman has described it (Goffman, 1961). Officers and prisoners become co-participants in enactments of realities characterised by criminal codes, conventions and practices, and penal ideals, procedures and actions. I have argued that these realities with their diverse value systems, legal statuses, moral orientations, ideals and means of establishing order and security are incompatible. I have also demonstrated how they are intertwined in daily practices where they are related because one makes possible the enactment of the other.

The result is, on the one hand, bewildering because we have lost an ideal conception of right and wrong as each others' opposites where one excludes the other. Furthermore, we have added a dimension to the uncertainties of prison life, the pains, by pointing to the doubts that the presence of multiplicity evokes because it is not always clear what realities are enacted and when. On the other hand, we have also gained: namely the necessity to rethink the two as simultaneous and united in the same locations, i.e. in prison and the enactments and experiences of people who live and work there. In so doing, prisons, officers and prisoners not only manifest a moral divide; they also enact a moral sameness that includes moral opposites. Following this line of argument, it is not a question of being trustworthy or untrustworthy, right or wrong, sincere or insincere, morally astray or morally on course, but rather a question of being and not being: a question of being both at the same time.

With Despret I have connected enactments with experience making ambiguity and ambivalence pivotal characteristics of adaptation and being in prison; characteristics that reflect the multiple realities of officers and prisoners and the relationships they have with each other.

In adapting to prison life, prisoners draw extensively on their networks in-and outside of prison to provide safety and collect information about staff, rules, regulations, daily life and the possibilities that this offers. In this context, I have argued staff play only a limited role. I have also argued that although prisoners' adaptive strategies are subject to change, and it is possible to diversify them, a general picture emerges nevertheless. In relation to the penal supportive and motivational work, adaptation mostly comes with a circumvention of a penal ideal moral project that staff assess prisoners in terms of, i.e.: by rewarding those who comply with it and resisting those who do not.

The moral project provides an institutional imperative and logic that, together with the implementation of penal policies, seek to stimulate individual prisoners to take responsibility for a morally aligned future and life. I have explained how prisoners mostly do take responsibility for their lives, however, in ways that are foreign to the penal system and its moral ideals. By pretending an alliance with institutional ideals, prisoners circumvent the moral project while, simultaneously, using institutional stimuli to pursue diverse individual ends. Against this background, I argue that prisoners deflate institutional power and appear to escape the regime and its ideals without leaving it.

I have also argued that in this context, institutional interaction can be perplexing when prisoners are met with staff resistance because they do not manage the art of convincingly pretending moral alliance, whereas prisoners who pretend with conviction are rewarded with good will. This typically happens when staff comes to regard prisoners as morally astray, insincere and untrustworthy because they communicate intentions in ways that do not honour the institutional logic and policies. It is against this background, staff appears, simultaneously, to implement ideals and policies that promote moral rightness and incentives schemes that favour those who are morally astray, hence, adding layers of ambiguity to prison life.

Although the Scandinavian regimes expose exceptional characteristics through their extraordinary good material conditions, their low levels of imprisonment and their ideal emphasis on punishment as deprivation of liberty only, these regimes may also come with additional challenges, as this analysis demonstrates. Prisoners' experiences of and adaptation to prison life are characterised by a striking lack of clarity that unveils a discrepancy between penal institutional ideals and practices; a discrepancy that calls for a rethinking of the implementation of punishment that is visionary and relevant because it reflects an awareness of penal everyday realities as they can be observed from within. 


\section{M. NIELSEN}

\section{REFERENCES}

Borish, S. M. (1991). The Land of the Living. Nevada City, CA: Blue Dolphin.

Bosworth, M., \& Carrabine, E. (2001). Reassessing resistance: Race, gender and sexuality in prison. Punishment and Society, 3, 501-515. doi:10.1177/14624740122228393

Clemmer, D. (1958). The prison community (2nd ed.). Chicago, IL: Holt, Rinehart and Winston.

Cohen, P. (1994). Self consciousness. An alternative anthro-pology of identity. London: Rutledge. doi:10.4324/9780203418987

Crawley, E., \& Sparks, R. (2005). Older men in prison: Survival, coping and identity. In A. Liebling, \& S. Maruna (Eds.), The effects of imprisonment (pp. 343-366). Portland, OR: Willan Publishing.

Crewe, B. (2009). Power, adaptation and social life in an English prison. Oxford: Oxford University Press.

Crewe, B. (2007). Power, adaptation and resistance in a late-modern men's prison. British Journal of Criminology, 47, 256-275. doi:10.1093/bjc/azl044

Crewe, B. (2005). The sociology of imprisonment. In Y. Jewkes (Ed.), Handbook on prisons (pp. 123-151). Portland, OR: Willan Publishing.

Christie, N. (2001). Kriminalitetskontrol som industri, på vej mod gulag, vestlig stil. Copenhagen: Hans Reitzels Forlag.

de Certeau, M. (1984). The practice of everyday life. Berkeley, CA: University of California Press.

Despret, V. (2004). The body we care for: Figures of anthropo-zoogenesis. Body and Society, 10, 111-134.

doi: $10.1177 / 1357034 X 04042938$

Einat, T. (2005). Soldiers, sausages and deep sea diving: Language, culture and coping in Israeli prisons. In A. Liebling, \& S. Maruna (Eds.), The effects of imprisonment (pp. 285-306). Portland, OR: Willan Publishing.

Engbo, H. J. (2005). Straffuldbyrdelsesret. Copenhagen: Jurist OG Økonomforbundets Forlag.

Flerårsaftale (2004). Agreement between the Danish government and the Danish folk party regarding the law of finance for 2004.

Garland, D. (1997). Governmentality and the problem of crime. Theoretical Criminology, 1, 173-214.

doi:10.1177/1362480697001002002

Gieser, T. (2008). Embodiment, emotion and empathy. An-Thropological Theory, 8, 299-318.

Goffman, E. (1961). Asylums, essays on the social situation of mental patients and other inmates. London: Penguin Books.

Graunbøl, H. M. (2010) Retur: En nordisk undersøgelse af recidiv blandt klienter i Kriminalforsorgen. Oslo: Bjerch Trykkeri.
Harvey, J. (2005). Crossing the boundary: the transition of young adults into prison. In A. Liebling, \& S. Maruna (Eds.), The Effects of Imprisonment (232-255). Portland, OR: Willan Publishing.

Hastrup, K. (2005). Towards a pragmatic enlightenment? Social Anthropology, 13, 133-149. doi:10.1017/S0964028205001199

Jackson, M. (1996). Things as they are. New directions in phenomenological anthropology. Bloomington, IN: Indiana University Press.

Järvinen, M., \& Mik-Meyer, N. (2003). At skabe en klient, institutionelle identiteter $i$ social arbejde. Copenhagen: Hans Reitzels Forlag.

Kriminalforsorgen (DfK) (2000). The prison and probation service. Denmark: Ministry of justice.

Kristoffersen, R. (2010). Nordisk statistik for Kriminalomsorgen $i$ Danmark, Finland, Island, Norge og Sverige. Kriminalomsorgens utdanningssenter KRUS.

Liebling, A. (1999). Prison suicide and prisoner coping. Crime and Justice, 26, 283-359. doi:10.1086/449299

Liebling, A., \& Arnold, H. (2004). Prisons and their moral performances: A study of values, quality, and prison life. Oxford: Clarendon Press.

Liebling, A., \& Maruna, S. (2005). The effects of imprisonment. Portland, OR: Willan Publishing.

Mathiesen, T. (1965). The defences of the weak. A sociological study of a Norwegian correctional institution. London: Tavistock Publications.

Mol, A. (2002). The body multiple: Ontology in medical practice. London: Duke University Press.

Pratt, J. (2008). Scandinavian exceptionalism in an era of penal excess. British Journal of Criminology, 48, 119-137. doi:10.1093/bjc/azm072

Ministry of Justice (2006-2009). Redegørelse om prøveløsladelse af dømte i med før af straffelovens paragraph 40a- "noget for noget” $i$ perioden fra den 1. april 2004 til den 31 marts 2005 [RoPaD]. Denmark: The Prison and Probations Service.

Rendtorff, J. D. (2004). Fœnomenologien og dens betydning. In L. Fuglsang, \& P. Olsen (Eds.), Videnskabsteori på tvœrs af fagkulturer og paradigmer (277-306). Frederiksberg: Roskilde Universitetsforlag.

Sparks, R. J., \& Bottoms, A. E. (1995). Legitimacy and order in prisons. The British Journal of Sociology, 46, 45-62. doi:10.2307/591622

Scharff Smith, P. (2003). Moralske hospitaler, det moderne feengselsveesens gennembrud 1770-1870. Denmark: Forum.

Sykes, G. M. (1958). The society of captives. Princeton, NJ: Princeton University Press.

Uglevik, T., \& Dullum, J. (1212). Penal exceptionalism? Nordic prison policy and practice. London: Routledge. 